\title{
Analysis on Real Estate Enterprise Cost Accounting Problem
}

\author{
Yu Gu, Yanan Yuan \\ Commercial College, Beijing Wuzi University, Beijing, China
}

\section{Email address:}

yyn603374055@163.com (Yanan Yuan)

\section{To cite this article:}

Yu Gu, Yanan Yuan. Analysis on Real Estate Enterprise Cost Accounting Problem. Journal of Finance and Accounting. Vol. 4, No. 6, 2016, pp. 336-341. doi: 10.11648/j.jfa.20160406.14

Received: September 19, 2016; Accepted: October 18, 2016; Published: November 15, 2016

\begin{abstract}
With the rapid and sustained development of China socialist market economy, the real estate industry has become the industry part that plays a dominant role in national economy. But the related accounting system of real estate enterprise is not perfect in China, and fails to have a full range of coverage, so part of the real estate enterprises will take advantage of the system vulnerabilities to do some illegal behaviors, including the manipulation of profits, the whitewash of statements and other violations, especially in the case of cost accounting. In this paper, by analyzing the reasons and current situation emerges in the cost accounting of the real estate industry in our country, will put forward corresponding countermeasures on the accounting of real estate enterprise accounting cost. In order to ensure the normal operation of the real estate business management, to ensure that the interests of investors, and then stabilize the socialist market economy to ensure that the formulation of state macro-control policy.
\end{abstract}

Keywords: Real Estate Enterprise, Cost Accounting, Countermeasures

\section{Introduction}

Accounting standards for enterprises in China 103rd provisions, enterprises should be based on the production and operation of the enterprise characteristics and management requirements, determine the cost of the enterprise accounting object, the cost of the project and the cost calculation method. Cost accounting object, calculation method of cost has been determined, shall not be arbitrarily changed, such as the need to change, should according to the management authority, the general meeting of shareholders or the board of directors, or the manager (director) approval of the conference or similar institutions, which shall be explained in the notes to financial statements. [1]

For the real estate development enterprise accounting, easy to carry out the "accounting standards for enterprises ", the ministry of finance formulated the "real estate development enterprise accounting system". Among them, the caption of account "development cost" in no. 401 is as follows: (1) Enterprises in the land, houses, all expenses incurred by the development process of supporting facilities and construction projects in the enterprise. Such as: the decoration and the addition of indoor facilities for rental housing and rental housing project expenditures. And for the leasing business in the development of products monthly accrued amortization of lease product development, can included in the "operating costs" subjects. For enterprises to raise funds and other financial activities and interest payments, and the business administration department for the organization and management of real estate development and operation management of costs incurred, as period costs, directly included in the current profits and losses. (2) Enterprises in the land, housing, the cost of the development process and supporting facilities in the construction project, including compensation for land requisition and demolition, preliminary engineering costs, infrastructure costs, construction and installation costs, infrastructure costs and indirect costs. The development for enterprises in the land expropriation and relocation compensation, pre engineering fees, infrastructure construction and installation fees, which belongs to the direct costs, directly included in the subject (the objects of cost accounting cost project); overhead cost burden by the development of products, should be first in "indirect costs" subject to collection, at the end of the month, according to the standard of distribution, distribution included in relevant the development cost of the product. In addition, the business development of the land, housing, infrastructure and construction projects, the use of a packet mode, should be 
made in accordance with contract enterprises "project price settlement bill" acceptance work Cheng, included in the subject (the cost of project cost accounting object), credit accounts payable, payable construction enterprises "subjects. The development of land, housing, self used facilities and construction projects, the cost, can be directly included in the course (about cost accounting object the cost of the project), credited to" stock material "," bank deposits "and other subjects. If the enterprise self construction of large-scale construction and installation engineering, according to the need for additional" construction "," construction cost accounting" and other subjects, to collect proprietary engineering construction and installation costs, at the end of the month, according to the actual cost of the enterprise into the subject. The recipients of the equipment in the process of real estate development, attached to the project entity, should be based on the attached object, to deliver equipment issued during installation, according to the actual cost in the course of credit, "inventory of equipment". When, according to the accrual basis and the income and the cost of the matching principle, should be a commercial housing product development costs, such as transfer not public facilities fees, the cost should be transferred in a commercial housing development and sales of the products shall be withholding, withholding, debit of the subjects, credited "accrued expenses" course. The difference between number and the number of actual expenditures for withholding, increase or decrease the development cost of the product. (3) The enterprise has been completed and acceptance of land, housing, infrastructure and construction project, should be timely costing. The end of month cost, according to the actual cost of debit "product development" subjects, credited to the subject. Enterprise to the rental housing decoration and facilities in the room added to the completion of the project, should be timely. Transfer the cost of the project, debit "lease product development" subjects, credited to the subject. (4) The enterprise should be based on the operating characteristics of the enterprise, the enterprise's cost accounting object, project cost and cost accounting method for detailed accounting development costs, it should be according to the type of development costs, such as "land development", "housing development", "facilities development" and "construction project" and other settings ledger, accounting for details on cost accounting object and project cost. [2]

For the development of indirect costs, through the system of No. 407th accounting subjects: (1) The development of indirect costs, indirect costs, internal independent accounting unit accounting of enterprises and for the development of products including wages, welfare expenses, depreciation costs, repair costs, office expenses, utilities, labor protection costs, the housing turnover amortized. To the enterprise, the administrative department (Headquarters) and for the organization and management of production and business activities of the management fees should be credited as period cost, "management fees". (2) The indirect expenses incurred by enterprises, the debit of the subjects, credited "wages", "welfare payable", "accumulated depreciation". "Housing turnover" and other subjects. (3) The development of indirect costs should be in accordance with the provisions of the enterprise cost accounting method, allocated costs related to the accounting object, debit "development costs", credited to the subject. (4) the development of indirect costs should be the end of all according to a The accounting object is allocated, and there is no balance. [2]

\section{Status Quo and Existing Problems of China's Real Estate Listed Companies' Cost Confirmation}

Cost accounting method of the real estate enterprises consists of three parts, namely land development cost accounting, the cost of housing development accounting, cost accounting and related facilities development. By the end of 2014, China's total of 144 real estate listed companies, the cost of production in general in the following manner. (1) For the development of cost accounting the product variety, direct costs according to cost accounting object collection, development and distribution of indirect costs by a certain proportion of the standards included in the relevant product development cost. (2) For a pure land development project, calculated per square meter of land development cost per unit, according to the purpose and use of the area, were calculated to develop products every detail project (. 3) For real estate development projects together with the overall, its cost can distinguish the burden of the object, according to the actual occupation area allocated to the cost of commercial housing. (4) The cost of public facilities accounting, where the development and construction of residential housing development costs included in the current synchronization; and where residential facilities are not synchronized, public facilities will not occur by general methods. First determine the withholding amount, according to the budget cost after approval from the development of the subject of pre extraction, until after each period of payment. [3]

The cost accounting method used at present, there are mainly the following two aspects: (1) Real estate accounting object has the particularity, and relatively complex, so should the time due to the accounting object, fully considering the relevant factors to confirm. The current cost accounting of our country is not perfect, and can not meet the accounting to determine the object demand, so there will be a lot of problems. The accounting object cannot be unified between enterprises, in the actual work will be divided carefully or too coarse arbitrary phenomenon. If divided carefully, will lead to many common costs need to allocate, if the division is too thick, it is difficult to reflect the actual cost of the level of development of the project. This will lead to confusion, so that the actual data become a lack of system, even will become unmanageable. Plus the cost allocation and cost allocation is not reasonable, it makes the problem more serious Heavy. To determine the accounting object, the enterprise has great randomness, the enterprise will confirm according to their own needs, or for other reasons, lack of principle, so the 
development of the actual cost of the project is difficult to control, there will be false, cause the distortion of accounting information, for enterprises to deliberately increase the cost and an important means to pay less tax. [4] (2) The cost of distribution and accumulation occurred is not perfect. In accordance with the provisions of the accounting system, expenses shall be included in the cost of the product, but for the burden of multiple objects will be the first to set, then the provisions of this redistribution. In order to let enterprises have to allocate a greater autonomy, a fair and reasonable allocation for enterprises. But there is no definite criterion cost allocation, distribution makes enterprises do not attach importance to cost, random distribution costs, any amortization expense, not Only enterprises will lead to confusion, will lead to a bubble economy, cause the distortion of accounting information. [5] To investors, creditors and the relevant government departments is misleading, making it difficult for them to grasp the enterprise operation ability and financial status, making the wrong decision, which will affect the company's normal operation, and even affect the order of the market economy and may cause investors hold. That lack of trust, hindering the construction of social morality. Real estate enterprises are mostly large enterprises, has a huge asset, so the accounting information of the extent of its influence is very wide. And if the real estate enterprise accounting information problems, not only damages the interests of investors, but also affects the health and stability of the socialist market economy system thus, the stability of socialist market economy is destroyed, there may even affect the national macro-control policies.

\section{Suggestions on Cost Accounting of Real Estate Listed Companies}

\subsection{Define the Cost Accounting Object}

Cost accounting object uncertainty, directly affect the operating results. It should be systematic, for the large range of unified classification, then a small range of cutting. For example for large projects, can be carried out on regional division of cost accounting, and then again divided, determine division of the smallest unit, and for small scale projects directly accounted for. [6] This is not only conducive to macroeconomic control, but also makes the distribution more reasonable, to ensure the quality of the information, even if it is divided into different engineering, finally have the same standard. [7]

\subsection{The Specific Collection and Institutional Cost of Real Estate Enterprises}

At present the real estate enterprise cost and not clearly defined. Therefore, in view of the particularity of real estate enterprises, recommended the introduction of a general cost of development projects only regulations. A house, the cost borne by the unit; development projects for many houses, the direct cost of every house shall be borne by each of them. The indirect costs can distinguish between categories, such as residential buildings, office buildings, commercial buildings and other categories, because of their previous expense fee rate standard is not the same as the percentage of cost of its commitment to the nature is not the same, to distinguish between categories, similar to further cost accumulation, such as the development of several residential buildings, should share the cost according to the direct cost of each one of the proportion.

\section{Conclusion}

Real estate accounting is internal guarantee for the healthy development of real estate. Yet the current form is still not optimistic, and the question remains. so the cost of real estate enterprise is an important performance. To solve the main problem, the specific collection and institutional cost of real estate enterprise is a good choice. [9] The real estate enterprise's development momentum cannot be prevented, and as a new generation of accounting workers will further improve the real estate enterprise accounting.

\section{Acknowledgement}

Fund project: the Beijing municipal science and technology innovation platform project "business and enterprise service innovation research"

\section{Appendix 144 Listed Real Estate Companies}

\begin{tabular}{llll}
\hline Code & Name & Operating Income (RMB Ten thousand) & Growth Rate (\%) \\
\hline 000036.SZ & Hualian holding co. LTD & $9,591.5535$ & -15.9739 \\
000402.SZ & Financial street holding co. LTD & $491,904.4665$ \\
000965.SZ & Tianbao infrastructure co. LTD & $35,902.5865$ \\
000638.SZ & Wisefund Investment holding co. LTD & $6,591.9949$ & $80,289.9414$ \\
600322.SH & Tianjin real estate development (group) co., LTD & $109,514.5751$ \\
600007.SH & China World Trade Center holding co. LTD & $114,755.2774$ \\
000029.SZ & Shenzhen special economic zone real estate (group) co. LTD. & $278,614.6131$ \\
000031.SZ & Cofco property (group) co., LTD & $232,675.8623$ \\
$000042 . S Z$ & Continental holding co. LTD & $9,908.8173$ \\
$000886 . S Z$ & Hainan expressway co., LTD & $61,693.8930$ \\
$000909 . S Z$ & Soyea technology holding co. LTD & -28.0781 \\
\hline
\end{tabular}




\begin{tabular}{|c|c|c|c|}
\hline Code & Name & Operating Income (RMB Ten thousand) & Growth Rate (\%) \\
\hline 000918.SZ & Jia KaiCheng group co., LTD. & $211,209.9830$ & -21.5018 \\
\hline 000981.SZ & Millions of the Bank's shares holding co. LTD & $212,136.5214$ & -19.3988 \\
\hline 000656.SZ & US shares holding co. LTD & $656,074.3004$ & 50.5475 \\
\hline 000691.SZ & Asia Pacific industry holding co. LTD & $3,342.9578$ & 202.5177 \\
\hline 000505.SZ & Pearl River holding co. LTD & $13,611.7829$ & 9.1698 \\
\hline 000514.SZ & Chongqing development holding co. LTD & $31,926.0845$ & -62.5371 \\
\hline 000526.SZ & Silver run investment holding co. LTD & $1,253.2677$ & 130.2794 \\
\hline 000006.SZ & Shenzhen zhenye group A holding co. LTD & $202,261.4400$ & 311.5284 \\
\hline 600113.SH & Zhejiang East holding co. LTD & $11,644.3113$ & -37.6970 \\
\hline 600734.SH & Shida group holding co. LTD & $5,491.5682$ & 444.5281 \\
\hline 600604.SH & City North high holding co. LTD & $8,048.4188$ & 3.9328 \\
\hline 600620.SH & Heaven in stock holding co. LTD & $2,557.0657$ & 36.3360 \\
\hline 600621.SH & Huaxin shares holding co. LTD & $29,854.2679$ & -21.4197 \\
\hline 600648.SH & Wai Gao Qiao holding co. LTD & $352,340.0728$ & 38.8689 \\
\hline 600649.SH & City investment holding co. LTD & $269,012.9074$ & -8.2955 \\
\hline 600675.SH & Chinese enterprises holding co. LTD & $127,258.5728$ & 14.2358 \\
\hline 600568.SH & Pearl holding co. LTD & $32,547.4740$ & -34.1925 \\
\hline 600576.SH & Good home holding co. LTD & 276.4738 & -67.4581 \\
\hline 600383.SH & Gemdale group holding co. LTD & $808,842.8817$ & -10.9584 \\
\hline $600240 . \mathrm{SH}$ & Uol capital holding co. LTD & $315,908.9428$ & 284.5788 \\
\hline 600890.SH & Room share holding co. LTD & 186.3968 & -68.6835 \\
\hline 600773.SH & Tibet city holding co. LTD & $18,223.3220$ & -65.9792 \\
\hline 600807.SH & Industrial Corporation holding co. LTD & $38,867.6046$ & 40.2483 \\
\hline 000931.SZ & Zhongguancun holding co. LTD & $39,896.6535$ & -64.3562 \\
\hline 000809.SZ & Tieling holding co. LTD & $1,250.8562$ & -93.2594 \\
\hline 000863.SZ & Sanxiang shares holding co. LTD & $21,756.7192$ & -67.9900 \\
\hline 000620.SZ & New Hualian holding co. LTD & $92,381.4957$ & 7.5333 \\
\hline 000534.SZ & Nwanze shares holding co. LTD & $27,128.5318$ & 1.8197 \\
\hline 000540.SZ & Transit City cast holding co. LTD & $804,400.7840$ & 54.8293 \\
\hline 000573.SZ & Guangdong Hongyuan A holding co. LTD & $20,059.9622$ & -62.2686 \\
\hline 000046.SZ & Oceanwide holding co. LTD & $400,251.0227$ & 88.3193 \\
\hline 002133.SZ & Guangyu group holding co. LTD & $58,463.2512$ & 122.8799 \\
\hline 000897.SZ & Jinbin development holding co. LTD & $43,802.1208$ & -62.8745 \\
\hline 600215.SH & Changchun economic development holding co. LTD & $9,166.6973$ & -9.8674 \\
\hline 600641.SH & Wanye enterprises holding co. LTD & $97,949.3235$ & 104.3647 \\
\hline 600658.SH & Electronic holding co. LTD & $16,522.8812$ & -85.0484 \\
\hline 600340.SH & Chinese happy holding co. LTD & $1,687,224.3734$ & 48.2298 \\
\hline 600376.SH & First shares holding co. LTD & $748,638.6249$ & -23.7451 \\
\hline 600225.SH & Tianjin Songjiang holding co. LTD & $19,237.1523$ & -53.8498 \\
\hline 600246.SH & Beijing vantone real estate holding co. LTD & $78,485.6196$ & 132.5605 \\
\hline 600159.SH & Great Dragon real estate holding co. LTD & $19,053.2025$ & -4.9977 \\
\hline 600185.SH & Gree real estate holding co. LTD & $11,517.1858$ & -86.7424 \\
\hline 600716.SH & Phoenix stakes holding co. LTD & $15,798.5890$ & -69.5934 \\
\hline 600748.SH & Real development holding co. LTD & $77,096.7939$ & 33.2102 \\
\hline 600759.SH & InterContinental oil and gas holding co. LTD & $65,335.7619$ & 85.2580 \\
\hline 000671.SZ & Sunshine City holding co. LTD & $448,814.2056$ & 46.1217 \\
\hline 000038.SZ & Dark Chase holding co. LTD & $9,725.7435$ & 85.3713 \\
\hline 002244.SZ & The Riverside group holding co. LTD & $594,516.2532$ & 36.8860 \\
\hline 002077.SZ & Jiangsu Dagang holding co. LTD & $67,824.3134$ & -26.4725 \\
\hline 000979.SZ & Zhonghong shares holding co. LTD & $67,883.8431$ & -70.7085 \\
\hline 600683.SH & Beijing investment Intime holding co. LTD & $62,960.3954$ & 431.8259 \\
\hline 600753.SH & East Silver Star holding co. LTD & 40.0000 & -69.7311 \\
\hline 600639.SH & Jinqiao holding co. LTD & $74,782.3050$ & -22.2371 \\
\hline 600393.SH & Donghua industrial holding co. LTD & $29,989.6983$ & 87.2834 \\
\hline 600223.SH & Lushun real estate holding co. LTD & $200,466.6534$ & 51.7390 \\
\hline 002208.SZ & Hefei urban construction holding co. LTD & $25,260.0695$ & -66.3733 \\
\hline 000668.SZ & Rongfeng holdings holding co. LTD & 445.9075 & -22.9904 \\
\hline 000670.SZ & Infront of micro holding co. LTD & $12,436.1217$ & 93.2005 \\
\hline 000040.SZ & Baoan District real estate holding co. LTD & $48,903.2479$ & 44.0638 \\
\hline
\end{tabular}




\begin{tabular}{|c|c|c|c|}
\hline Code & Name & Operating Income (RMB Ten thousand) & Growth Rate (\%) \\
\hline 000056.SZ & Dark country holding co. LTD & $17,042.3405$ & 356.2617 \\
\hline 000150.SZ & Yihua Health holding co. LTD & $42,164.1046$ & 430.0929 \\
\hline 000961.SZ & Zhongnan construction holding co. LTD & $882,100.4573$ & -7.2064 \\
\hline 000024.SZ & Investment real estate holding co. LTD & $1,797,394.8437$ & 12.0071 \\
\hline 000090.SZ & Tonge group holding co. LTD & $273,820.2392$ & 54.0876 \\
\hline 002285.SZ & World-link holding co. LTD & $191,552.2311$ & 35.2288 \\
\hline 600606.SH & Green holding co. LTD & $8,612,346.0741$ & -26.6700 \\
\hline 600239.SH & Yunnan quasi- holding co. LTD & $28,211.7571$ & -57.9201 \\
\hline 600158.SH & China industry holding co. LTD & $26,814.4112$ & -32.3238 \\
\hline 600048.SH & Poly real estate holding co. LTD & $4,234,496.1790$ & 24.5465 \\
\hline 600052.SH & Zhejiang guangsha holding co. LTD & $39,009.1153$ & -15.1465 \\
\hline 600684.SH & Pearl River enterprises holding co. LTD & $100,360.3157$ & 4.8903 \\
\hline 600732.SH & *ST New plum holding co. LTD & $4,344.4743$ & -60.7150 \\
\hline 002146.SZ & R development holding co. LTD & $915,221.6167$ & -10.0156 \\
\hline 000797.SZ & China Wuyi holding co. LTD & $100,185.3992$ & 1.2462 \\
\hline 000803.SZ & Kim car city holding co. LTD & $4,550.6358$ & -35.7027 \\
\hline 000014.SZ & Shahe shares holding co. LTD & $18,403.5355$ & -4.2407 \\
\hline 002305.SZ & Southland real estate holding co. LTD & $60,476.5306$ & 4.7290 \\
\hline 600895.SH & Zhangjianggaoke holding co. LTD & $50,613.7752$ & -30.1136 \\
\hline 600791.SH & Beijing energy real estate holding co. LTD & $27,127.0343$ & -65.2725 \\
\hline 600724.SH & Ningbo fuda holding co. LTD & $111,164.8807$ & -69.7109 \\
\hline 600638.SH & New harbour holding co. LTD & $64,447.8947$ & -5.3746 \\
\hline 600647.SH & Tongda venture holding co. LTD & $6,499.1395$ & -0.2402 \\
\hline 600657.SH & Cinda real estate holding co. LTD & $216,327.0378$ & 13.4913 \\
\hline 600665.SH & World source holding co. LTD & $31,611.0374$ & -61.0145 \\
\hline 600533.SH & Qixia formation in construction holding co. LTD & $303,759.9070$ & 144.0416 \\
\hline 600325.SH & Hua FA shares holding co. LTD & $223,252.4299$ & 11.8463 \\
\hline 000506.SZ & Run resource holding co. LTD & $29,281.7066$ & 74.3019 \\
\hline 000043.SZ & Air real estate holding co. LTD & $161,340.7478$ & -17.8980 \\
\hline 600823.SH & Shimao shares holding co. LTD & $852,604.4247$ & 39.3871 \\
\hline 002016.SZ & Rong Zhaoye holding co. LTD & $61,765.2370$ & 106.8732 \\
\hline 000069.SZ & Overseas Chinese town A holding co. LTD & $1,016,133.3341$ & -25.2657 \\
\hline 601588.SH & North Star industrial holding co. LTD & $324,946.6815$ & 25.4670 \\
\hline 600149.SH & Langfang development holding co. LTD & 138.3147 & -92.9672 \\
\hline 600175.SH & United States energy holding co. LTD & $239,533.0620$ & 7.2295 \\
\hline 600095.SH & High-tech holding co. LTD & $10,605.0895$ & -62.8661 \\
\hline 600777.SH & Fashion industry holding co. LTD & $18,087.1178$ & -60.5677 \\
\hline 000838.SZ & Country real estate holding co. LTD & $50,216.1204$ & 50.6579 \\
\hline 600622.SH & Garbo group holding co. LTD & $103,355.4222$ & 7.7283 \\
\hline 000002.SZ & Vanke A holding co. LTD & $5,026,679.7993$ & 22.7160 \\
\hline 000631.SZ & Shunfa hengye holding co. LTD & $199,402.6706$ & 80.1200 \\
\hline 000011.SZ & Depth property A holding co. LTD & $33,876.1310$ & -32.4325 \\
\hline 000502.SZ & Green view holding co. LTD & $1,248.0459$ & -10.9193 \\
\hline 600745.SH & Zhongyin shares holding co. LTD & $37,618.0435$ & -50.3763 \\
\hline 600162.SH & Hong Kong holding co. LTD & $186,087.6448$ & 43.6965 \\
\hline 600266.SH & Beijing urban construction holding co. LTD & $327,457.8817$ & -7.0524 \\
\hline 000926.SZ & Lucky Star shares holding co. LTD & $374,675.0917$ & -9.0261 \\
\hline 000609.SZ & Cotton stock holding co. LTD & $2,778.0289$ & 63.1192 \\
\hline 000732.SZ & CAC Group holding co. LTD & $416,556.6415$ & 84.8540 \\
\hline 000736.SZ & Real estate holding co. LTD & $30,778.8893$ & -33.3508 \\
\hline 600555.SH & Dragon Mountain holding co. LTD & $9,825.6024$ & $1,577.2099$ \\
\hline 600736.SH & Suzhou high-tech holding co. LTD & $125,311.3985$ & -16.2466 \\
\hline 600503.SH & Gorgeous family holding co. LTD & $5,157.6308$ & -80.6082 \\
\hline 000718.SZ & Suning universal holding co. LTD & $376,389.0483$ & 609.3287 \\
\hline 600767.SH & Wan Shing Medical Therapy holding co. LTD & $1,084.9352$ & 64.5849 \\
\hline 600463.SH & Airport shares holding co. LTD & $26,297.0037$ & -30.6622 \\
\hline 000567.SZ & Hyde shares holding co. LTD & 937.3585 & 422.2696 \\
\hline 000608.SZ & Sun shares holding co. LTD & $34,324.2000$ & 40.6585 \\
\hline 600743.SH & Huayuan property holding co. LTD & $218,872.0838$ & -42.7516 \\
\hline
\end{tabular}




\begin{tabular}{llll}
\hline Code & Name & Operating Income (RMB Ten thousand) & Growth Rate (\%) \\
\hline 600094.SH & Big city holding co. LTD & $206,384.2966$ & 82.3065 \\
000616.SZ & Investment in HNA holding co. LTD & $29,949.0221$ & -26.5262 \\
600565.SH & Dumas shares holding co. LTD & $239,739.9525$ & -13.8594 \\
000517.SZ & Rong an real estate holding co. LTD & $28,465.5671$ & -88.9776 \\
600696.SH & Convex horse horses holding co. LTD & -0.3585 & -100.0359 \\
600615.SH & US shares holding co. LTD & $3,569.8528$ & 7.1830 \\
600663.SH & Lu Jia Zui holding co. LTD & $250,534.3229$ & 31.0705 \\
600064.SH & Nanjing high-tech holding co. LTD & $158,323.9051$ & 0.4490 \\
600173.SH & Wolong real estate holding co. LTD & $67,122.7511$ & 21.2171 \\
000558.SZ & The Rhine sports holding co. LTD & $118,073.8633$ & 14.1428 \\
600208.SH & Xinhu zhongbao holding co. LTD & $497,961.4361$ & 73.7530 \\
600067.SH & First city kingberry Chase holding co. LTD 292,264.1210 & -18.4697 & \\
000005.SZ & Century star holding co. LTD & $3,628.5339$ & 52.0984 \\
000537.SZ & Guang Yu development holding co. LTD & $67,310.057$ & 29.6841 \\
000667.SZ & Good group holding co. LTD & $104,928.4729$ & -3.7344 \\
\hline
\end{tabular}

\section{References}

[1] The ministry of finance. The accounting standard for business enterprises [M]. Beijing: economic science press. 2006

[2] Finance. The accounting standard for business enterprises [M]. Beijing: people's publishing house. 2010

[3] Chen Yujie, Chen Xinguo. Real estate development enterprise accounting and financial management [M]. Joint publishing house of China business. 2013

[4] Huang Chongyu. Discussing the problems and countermeasures in Real Estate Accounting [J]. Foreign investment in China, 2013 (20): 172

[5] Qian Jian. Problems existing in the real estate enterprise

income and cost accounting and perfecting countermeasures [J] Accounting 2010 (03): 90-91

[6] Linghong Yuan. Analysis on the common problems of accounting cost accounting in real estate enterprises [J] Finance and Accounting Research. 2011 (20): 246-247

[7] Bo Jing. Analysis on the financial report of China Vanke Real Estate Enterprise in 2010 [J] Accounting of Chinese township enterprises 2011 (11): 23-124

[8] Zitong Min. Analysis on the real estate enterprise cost accounting problem [J] Manager' Journal 2014 (13): 203-204

[9] Xiaoyan Guo. The cost accounting of real estate investment and development in China [J] The window of the accounting 2010 (02): 124-125

[10] Shuping Li. Discussion on the cost accounting of real estate enterprises [J] Accounting practice 2011 (09): 86-87 